\title{
Religion in a medieval European city
}

\author{
Svetlana Birk * \\ BSTU named after V.G. Shukhov, 308012, Belgorod, Russia
}

\begin{abstract}
Modern megacities are becoming spaces where religious processes unfold most actively. And this poses the problem of studying the functioning of religion in urban space. Cities always were religious centers, religion defined social behavior, but the specificity of the urban way of life left its mark on religion and influenced religious evolution. This article attempts to explore the interaction of religion and the urban environment in its wide historical context. The conditions for the existence of a historical religion (Christianity) in a medieval European city contributed to the transition of religion to a new stage of historical evolution - to the emergence of an "early modern religion" (Protestantism), which led to a radical disenchantment of the social world and the concentration of religiosity in the human inner world. A new type of religiosity, embodied in Protestantism, has become one of the factors contributing to the modernization process.
\end{abstract}

\section{Introduction}

In Middle Ages, Europe remained the agricultural world for a long time. The ancient cities disappeared or fell into decay in order to form a peculiar medieval city; the process took several centuries. The rise of European cities had began by the second millennium of a new era. The emergence of cities led to the flourishing of European culture, as well as profound socio-economic changes, which ultimately led to the destruction of the medieval way of life. D. Bell wrote: "A new social system ... does not always arise in the bowels of the old, but in some cases outside it. The basis of feudal society was nobles, landowners, military, clergy, whose wealth was associated with ownership of land. Bourgeois society, which originated in the XIII century, consisted of artisans, merchants, and free professionals, whose property is their qualifications or their willingness to take risks and whose earthly values are completely incompatible with the outgoing theatricality of a chivalrous lifestyle. However, it originated outside the feudal landowning structure, in free communities or cities, which by that time had already freed themselves from vassal dependence. And these small self-governing communities became the basis of European commercial and industrial society"[1].

This clearly led to the urgent task of exploring the impact of the urban environment on the religious ideas modification in traditional societies, as well as exploring the specifics of the religion presence in the urban space of medieval Europe.

\footnotetext{
* Corresponding author: bagdasarova-svet@mail.ru
} 


\section{Research method}

We used general scientific methods of analysis and synthesis, typology, generalization and classification, as well as historical, comparative and culturological research methods.

It should be noted that, in theoretical terms, the work is based on the evolutionary approach to the analysis of the history of religion, developed by R. Bella [2] and his typology of religions, which includes historical and early modern religions.

Thus, we will consider a model of the religion interaction and the city in the era of the European Middle Ages, since it is in Europe that the transition to the modern era took place.

\section{The history of religion development in a medieval European city}

Medieval cities arose, as a rule, around the castle-fortress of the seigneur, as its craft and trade suburbs. As Weber [3] noted in his famous study of a European city, initially a significant part of the population of these cities probably consisted of people serving in the senior. However, the urban population grew due to newcomers, and this population was initially heterogeneous in its origin and occupation (heterogeneity of the population, as we noted above, is one of the important signs of the city). Cities were necessary for the lords first of all to get income, they were situated on the land belonging to the lord and, thus, depended on him.

Strengthening cities, increasing the urban population, increasing the wealth of cities, the need for their own effective management system, which the seigneur, who was only interested in generating income, could not provide, all this led to an increase in contradictions between cities and seniors, the cities fought for their independence, and this the struggle often took on conflicting forms. The struggle of cities for their independence was the essence of the "communal movement" or "urban revolution" during X - XIII centuries.

Throughout Western Europe in the X-XIII centuries the political struggle began - the struggle of the city and the lord, the city and the king, which in historical science was called the communal movement: "In different regions of Western Europe, the communal movement had its own character. In Northern and Central Italy and Southern France, the city in the X-XII centuries got independence. In Italy, the large and middle northern cities received the status of city-states. Many cities in German lands also gained independence. Some cities in German lands received the status of city-republics. They were governed by a city council led by a burgomaster. These cities lived under Magdeburg Law, designed specifically for the city of Magdeburg, hence its name. Magdeburg Law which provided the city with the form of the highest and broadest self-government was a classic law of urban independence" [4].

As a result of the communal movement, many German cities gained independence Hamburg, Bremen, Frankfurt am Main and others, the cities of Northern France, the city of Flanders. The fate of the cities that were in the possession of the kings was more difficult. Kings regarded the city as their own treasury and did not want to grant them independence. In fact, not a single royal city received full self-government.

\section{Medieval city society}

The prevailing medieval cities were, in fact, to one degree or another, self-governing commercial communities. The population was engaged in various types of crafts and 
related intellectual and commercial activities. Craftsmen and other professionals were united in workshops that provided group solidarity and identity, as well as regulating professional activities. Cities represented a wide space for individual activity, much more than a rural way of life. Despite the fact that many citizens did not completely lose touch with the land - they had land outside the city; the medieval city contrasted itself with the village. Relocation to the city made a person free from networks of traditional dependencies - "the air of the city makes a person free." Cities were proud of their independence and liberties. "Those who enter the city must publicly get rid of any sign of inequality, just as the stones needed to build a building must be leveled and tree trunks freed from branches, growths, and planed. Members of the new society must openly express their will to unite, unite in organizations that do not aim at gaining profit, and use the principles of selfless mutual assistance. The city was a society of equality and mutual assistance" [5].

At the same time, social contrasts and inequality were more pronounced in cities than in the countryside. The city was also an arena of conflicting interests - both economic and political. All this made life in the city less predictable and more diverse than rural life.

But how did the medieval city interact with religion? Medieval Europe was the Christian world. Christianity permeated all spheres of social and cultural life. Within the framework of Christianity, it was impossible to consider each city as the habitat of its deity, God was one for all. Interaction with the Christian God implied other forms of ritual practices than the rituals of archaic religions. In addition, Christianity as a historical religion separated the earthly and heavenly worlds; therefore it was impossible to directly correlate urban institutions with mythological models, as was the case in cities of ancient civilizations. City institutions and various kinds were not directly derived from God's actions. However, this does not mean that there was no coordination of the earthly and heavenly. Each city and each workshop had their own especially revered saints, patronizing these groups. The rituals performed by the church accompanied all the significant events of city life and, naturally, of every person.

As a result, the growth of European cities was accompanied by the construction of cathedrals; the Gothic style is an urban phenomenon. Each city had a temple or several temples. The cathedral was the architectural dominant of the city. Almost all major cities were at the same time the residences of bishops. Temples were built with the money of the city; individual temples could be built with the money of individual workshops. Providing funds for the construction and decoration of the temple was a frequent pious deed and private individuals - wealthy citizens. Stained glass windows and sculptural compositions that adorned the cathedrals often reflected the occupations of the townspeople and sometimes even themselves, which reflected the desire of people not only to perpetuate their affairs, but also to sanctify them, thus bringing them closer to God. The cathedrals served not only for joint participation in the ritual, but also for other meetings of citizens, it was the home of the city community.

Thus, in the medieval city, religion was still directly present in the life of the townspeople, although the form of its influence has changed. It was not the idea of the literal, "material" presence of a god or gods next to people that came to the fore, but, on the contrary, the need for moral improvement in order to spiritually approach the transcendental God. Religious regulation, while maintaining the importance of the ritual component, now included moral reflection. Moreover, in the Christian worldview, as noted above, there is a wary attitude to the city, the awareness of the sinfulness of the "earthly city" [6] influenced the perception of cities and urban life of Middle Ages.

The medieval city remained a religious space where the presence of religion was visible and ubiquitous. However, this presence implied more than ritual. Moral perfection stimulated reflection; this contributed to a more rational approach to faith. Rationality also developed within the church itself - in the form of theology. Medieval universities, whose 
development was also associated with the development of cities and urban culture, were part of the church - and at the same time secular disciplines were taught there. At cathedrals in cities, schools often existed. The urban lifestyle itself, the development and complication of craft, and the expansion of trade contributed to the accumulation of secular knowledge of applied, practical purposes.

Thus, the development of cities and urban culture contributed to the intellectualization of life, behavior - and religious faith. Together with the inevitable individualism inherent in the urban structure, the growth of reflexivity and rationalism led, ultimately, to the next stage in the development of religion - there is Protestantism, which R. Bella [7] attributed to the early modern religions.

\section{Protestantism and its occurrence}

Protestantism was brought to life precisely by a conscious, moral-critical attitude to the existing form of religion embodied by the Catholic Church, as well as by the need for a more personal and conscious attitude to faith. Initially, criticism of the Church by the founder of Protestantism, Martin Luther, was not aimed at abandoning the church, but was aimed at eliminating the moral defects that were inherent in it. However, the result, as you know, was different from the original intentions. Protestantism rejects the need for the church and completely changes the practice of salvation and the form of religious behavior.

It can be stated that the emergence of the city in antiquity was associated with the evolution of religious beliefs, the transition from "primitive religion" to "archaic", according to the typology of R. Bella. The ancient city had religious functions and was perceived as a sacred space. Almost all city institutions and activities had a religious component. Temples were the most important city institutions, the patron deities of the city were thought of as being present in their temple dwellings. A common cult turned the city into a single community.

As a result, the specifics of the urban lifestyle predetermined the further evolution of religiosity. Structural differentiation, the complexity of culture, the emergence of structural tensions in urban antiquities led to the emergence of new worldview and ethical issues and practices - critical reflection, awareness of the imperfection of the world, the search for the "right way of life" and ways of salvation. It was the emergence of these phenomena that K. Jaspers considered as the essence of "axial time" [8]. In the typology of R. Bella, the emergence of these phenomena means the emergence of a new type of religion - historical religion, with its inherent features: "doubling the world", the depreciation of earthly being in comparison with super-valuable transcendental being, orientation toward ethical, rather than natural-cosmic problems, achievement personal salvation as the main goal of the believer life.

\section{Conclusion}

The existence of a historical religion in urban space was examined using medieval European cities as an example. It was shown that the life of a European medieval city, like the life of earlier cities of antiquity, was closely intertwined with religion, but the forms of interaction of religious and secular life in them differed. The differentiation between religious and secular aspects of activity in European medieval cities was more clearly expressed which was determined by the specificity of Christianity as a historical religion. Cities were no longer habitats of patron gods. They were secular, commercial communities of citizens whose worldview and ethics were influenced by the Christian doctrine of salvation, and social behavior was largely determined by the Catholic Church as the most 
influential institution of medieval society. However, with all the influence of Christianity both on the minds of people and on institutions, between the secular and religious aspects of life there was a conscious difference. Nevertheless, the medieval European city remained a religious city, secular life, for all its importance, was not considered as intrinsic value and the degree of religious regulation was very high.

Based on the foregoing, we can conclude that the uniqueness of this urban type of religiosity created the prerequisites for the emergence of an early-modern type of religiosity, which led to a radical spell of the social world and the concentration of religiosity in the inner world of man. A new type of religiosity, embodied in Protestantism, has become one of the factors contributing to the modernization process.

\section{References}

1. D. Bell, The coming post-industrial society (Moscow 1999).

2. R.N. Bellah, Religious Evolution, American Sociological Review, 29(3), 358374 (Jun., 1964)

3. M. Weber, City. Favorites. The image of society, Moscow, (1994)

4. V.V. Kareva, History of the Middle Ages (PSTBI, Moscow, 1999).

5. Le Goff J., Urban metaphor of Guillaume of Auvergne (The Medieval World of the Imaginary, Moscow, 2001)

6. Le Goff J., Knight-warriors and townspeople-winners (The medieval world of the imaginary, Moscow, 2001)

7. R. Bella, The main stages of the evolution of religion in the history of society. Religion and society (Reader on the sociology of religion, Moscow, 1996)

8. K. Jaspers, The meaning and purpose of history (Republic, Moscow, 1994) 